\title{
1. Weaving the hashtag into the fabric of legality
}

Recent years have witnessed a series of significant Western terror attacks, placing the threat of terrorism as a more prominent fixture in everyday life. Commensurate with the importance individuals place on social media in their lives, the immediate emotional public responses to these attacks are principally communicated across social media platforms. Because social media is now commonplace and such an integral part of everyday interactions, its platforms have become spaces where proliferating voices contribute to public debate about law, politics, and justice, as individuals openly share personal responses to provocative and everyday events. In our contemporary networked world, social media platforms now constitute a dominant mechanism through which individuals can communicate, debate, and influence one another on a global scale, and for many, commenting on societal issues has become the predominant form of participation in political life. ${ }^{1}$ Over the last decade in particular, the various platforms of social media have substantially intensified (and amplified) possibilities for public interpretation of political events, cultural crises, and significant social movements.

As high-profile terrorist attacks have become more visible within the public consciousness during that time, so too have social media interactions increasingly become viable modes for behavioural responses to those events. In the immediacy of a terror event, we are confronted by an encounter (even distantly) of tragedy and trauma. It is a reminder, in those moments, of the fundamental importance of law and its role in shaping the polity in which we live. Drawing conceptually upon a cultural legal studies framework that recognises law at the heart of everyday life, this book uses the analysis of comments posted to a social media platform (Twitter) to draw attention to the affective and cognitive uses

Carolyn M Hendriks, Sue Regan and Adrian Kay, 'Participatory Adaptation in Contemporary Parliamentary Committees in Australia' (2019) 72 Parliamentary Affairs 267, 269. 
individuals make of terror events to reassert normative values of law, legality, and justice in the world.

The book features analysis from an empirical project conducted over a number of years that explored the complicated and nuanced ways in which terror attacks are a catalyst for the public to articulate their perceptions of law and concepts of justice on Twitter. The project involved a suite of terror event case studies: the 'Sydney Siege' - the Australian hostage crisis in a Lindt Café 2014; the Paris 2015 and Brussels 2016 terrorist attacks; the London Westminster Bridge terrorist attack in March 2017; and the Christchurch Mosque attack in New Zealand, 2018. These acts of terror were dramatic local events that were experienced and viewed globally. ${ }^{2}$ Following each event, natural outpourings of anguish, anger, resentment, and grief were concentrated through mainstream and social media engagement into a collective narrative of fear and vulnerability. At these times, social media platforms become hyper-active, with voyeurism transformed into dynamic conversation that responds in real time to each event as it is reported by both mainstream media and citizen journalists.

As will be demonstrated, emotional reactions to terrorist attacks articulated on social media are a very real part of the mediated experience of coping for the public in those moments. As individuals attempt to come to terms with the implications of these events for everyday life, their extemporaneous public comments reflect and provoke a number of questions surrounding complex issues of protectionism, identity, trust, and the conflation of law and justice. In turn, narratives of law are produced that enliven and fuel juridical binaries: safety/danger, freedom/control, security/insecurity, order/disorder. While the narratives of social media can seem inexhaustible and varied, this book will demonstrate that they have become a new and significant method for informing and constituting law, as well as provoking critique and challenge to our cultural justifications for legality and justice.

2 Julie Posetti, 'Q\&A: How the Sydney Siege Was Reported by the Public and News Professionals' (The Conversation, 16 December 2014) <https:// theconversation.com/qanda-how-the-sydney-siege-was-reported-by-the-public -and-news-professionals-35518> accessed 8 August 2021. Posetti has argued that communication of traumatic crisis events no longer relies 'exclusively on mainstream media reporters bound by traditional publication deadlines', but instead, the prolific everyday activity of social media now ensures that local events are played out instantly to a global audience. 


\section{LEGALITY AND SOCIAL MEDIA}

My heart goes out to all of the victims, families and friends. I can not even imagine their pain. I'm so sorry the law failed to protect their loved ones. ${ }^{3}$

The tweet extracted above illustrates the intersectional activity of law and social media, and reflects the dual layers of analysis undertaken for this book. The first is to highlight the way that social media storytelling (commenting, posting, or tweeting) can give rise to a collective narrative that questions the efficacy of law in our society. The second layer further extends the analysis to demonstrate that social media narratives can render visible the ways in which legality is actively at work in our culture and consciousness.

To speak of legality as opposed to law is to refer to 'the meanings, sources of authority and cultural practices that are commonly recognised as legal, regardless of who employs them or for what ends' ${ }^{4}$ Legality in this sense is distinguished from the formal enactments and processes of law that operate in visible, official, and institutional ways, and includes the discourses of law that are multiple and varied. Crawley and Peters have argued that legality involves the 'subjection of domains of life to a knowledge structured by legal concepts, practices and methods, and the colonisation of disciplinary modes of life by juridical forms' ${ }^{5}$ Ewick and Silbey's rendering of legality alternatively suggests that individuals may participate in the remediation of law's presence by invoking and enacting 'legality in ways neither approved nor acknowledged by the law'. ${ }^{6}$ For me, to study legality is to be invested in both perspectives: where law enmeshes life AND where life entangles the law. That is, I am interested

3 Comment posted on Twitter in response to the terror event in Christchurch, New Zealand. Tweets are paraphrased and de-identified as discussed in Chapter 3 . Each tweet will be hereafter referenced by a code corresponding to the dataset on file with the author. That is, each tweet is allocated a number and paired with a B, L, NZ, P or S for Brussels, London, New Zealand, Paris, or Sydney related tweets, respectively. The one quoted here is thus coded: Tweet NZ696.

4 Dave Cowan and Helen Carr, 'What's the Use of a Hashtag? A Case Study' (2016) 43 Journal of Law and Society 416, 418.

5 Karen Crawley and Timothy D Peters, 'Introduction: "Representational Legality"' in Timothy Peters and Karen Crawley (eds), Envisioning Legality: Law, Culture and Representation (Routledge 2019) 6.

6 Patrick Ewick and Susan Silbey, The Common Place of Law: Stories from Everyday Life (University of Chicago Press 1998) 22. 
in the ways legal meaning is translated in and through everyday life and to shine a light on previously under-recognised ideas, meanings, and values. This work is also manifest in what Gies recognises as a legal consciousness 'which firmly situates the law at the heart of everyday life'? With a focus on such a perspective, my desire in this book is to showcase the use of social media narratives as an additional space through which to explore legality. The uncertain and rapidly changing context of crisis events, like terrorism, provoke vulnerabilities, both individually and communally, and social media hashtags provide an accessible and timely mechanism to weave together communal legal consciousness about the event. This book argues that there is indeed much utility in viewing legality this way, as a set of practices and processes by which states of mind and meanings about law are constructed, because "these states of mind are affected by events, situations and the like in society as a whole, and they lead in turn to actions that have an impact on the legal system itself' ${ }^{8}$ Adopting this perspective of legality rebukes traditional positivist accounts of law that have privileged the myth of legal autonomy. Legality as collectively understood, transformed, and (re)circulated through social media, actively challenges the passive formalism of law because it recognises that legal meaning is "continuously structured and restructured through an ongoing and fluid process of text-audience-media interaction within a broader socio-political context'. ${ }^{9}$ When using the term 'legality' in this book, I am referring to this dynamic and energising imbrication in which individuals are involved in active transformation and construction of legal meaning. ${ }^{10}$

The various case study analyses presented here explore how narratives of terror articulated on social media 'speak to, and provoke, particular

7 Lieve Gies, 'The Media and Public Understanding of the Law' in Steve Greenfield and Guy Osborn (eds), Readings in Law and Popular Culture (Routledge-Cavendish 2008) 74.

8 Ibid 35.

9 Anne Aly, 'Shifting Positions to the Media Discourse on Terrorism: Critical Points in Audience Members’ Meaning-Making Experiences' (2010) 134 Media International Australia 31, 33.

10 Thornton argues that the law must not seek to 'immunise itself from that which has been constituted as quotidian and mundane within the social script'. Margaret Thornton, Romancing the Tomes: Popular Culture, Law and Feminism (Routledge-Cavendish 2002) 18. 
anxieties about law and desires for particular kinds of legality'. ${ }^{11}$ The two key questions examined throughout these analyses are: How does emotional tweeting in response to a terror event produce legality? And how is legal meaning perpetuated and/or resisted within social media narratives in moments of terror? What is revealed in response to these questions is the symbiotic connection between emotion, narratives, and legal meaning-making that is animated within, and proliferates through, interactions on social media. In short, to tweet is to imbue (and be imbued with) legality. ${ }^{12}$ The analysis presented in the chapters to come demonstrates that as individuals tweet a response to particular events, they are drawing on emotions, cultural narratives, and pre-existing ideas of law to construct meaning about, and contribute to, legality. Such work underlies the theoretical and methodological framework that is at the heart of this research: cultural legal studies.

\section{CULTURAL LEGAL STUDIES - LAW AS ACTIVE CULTURAL REALITY}

In order to arrive at a meaningful understanding of law, one might look to the ways in which law is encountered, shaped, and conceived in popular cultural formations; or to the ways in which law is constructed, transformed, and manifested in the consciousness of its subjects. ${ }^{13}$ In this book, I argue that a hashtag jurisprudence does both. This necessitates a brief explanation of the conceptual basis for understanding 'culture' itself. Here, the analysis is contexualised within three considerations of culture informed broadly from anthropology: (i) behavioural - culture is shared, it is learned human behaviour, and it is a way of life; (ii) normative - culture is ideals, values, or rules for living; and (iii) structural - culture consists of patterned and interrelated ideas, symbols, or

11 Austin Sarat, 'What Popular Culture Does for, and to, Law: An Introduction' in Austin Sarat (ed), Imagining Legality: Where Law Meets Popular Culture (University of Alabama Press 2011) 6 .

12 Dave Cowan and Helen Carr, 'What's the Use of a Hashtag? A Case Study' (2016) 43 Journal of Law and Society 416, 431.

13 Desmond Manderson states: 'For as long as there has been law (and there has always been law), and for as long as there has been culture (and there has always been culture), there has been a relationship between them': Desmond Manderson, 'Trust Us Justice: 24, Popular Culture, and the Law' in Austin Sarat (ed), Imagining Legality: Where Law Meets Popular Culture (University of Alabama Press 2011) 22. 
behaviours. ${ }^{14}$ The interconnected nature of these definitions means that the concept of culture has developed into a social description of the daily lived experience where the focus is on meaning. This broad understanding emphasises that culture is comprised of a set of meaningful discourses that provide a way of speaking and viewing the world. By seeking to ask questions about how meaning is actually produced, transformed, shared, and contested among individuals, 'culture' is seen as not just an understanding of a 'way of life', but further, as an exploration of the production and circulation of meaning within all social practice that is reflected in the values, speech, symbols, and actions of the individuals. Of course, social media interaction has become a significant mechanism for such meaning-making processes in modern-day life. Through social media posting, tweeting, and sharing, individuals can instantly join and contribute to what Geertz called 'webs of significance'. ${ }^{15}$ This shared aspect of culture, whereby constructions of meaning spun by humans are interpreted and shared with others, is the notion of culture that it is utilised in this book, and is one that connects with the more contemporary attentiveness to "the imaginative life of the law and the way law lives in our imagination'. ${ }^{16}$

Extending this approach, as law is a quotidian aspect of the social experience and 'is inseparable from the interests, goals, and understandings that deeply shape or comprise social life', ${ }^{17}$ it is necessary to appreciate how individuals produce, interpret, transform, and exchange meanings about legality through new forms of technology. When people engage with social media, they are engaged in the production and the exchange of meanings, ${ }^{18}$ in order to interpret the world (and law) in a meaningful way. ${ }^{19}$ What is important is not what people know about the law, but how they use it to construct and transform meaning.

14 John H Bodley, Cultural Anthropology: Tribes, States, and the Global System (Mayfield Publishing Co. 1994) 10.

15 Clifford Geertz, The Interpretation of Cultures: Selected Essays (Basic Books 1973) 4-5.

16 Austin Sarat and Thomas R Kearns, Law in the Domains of Culture (University of Michigan Press 1998) 6.

17 Ibid.

18 Stuart Hall, Representation: Cultural Representations and Signifying Practices (Sage Publications 1997) 2.

19 Ibid 17. 
While the yoking of culture and law has been recognised in many other disciplines for over a century, ${ }^{20}$ their interconnectedness has not always been appreciated by traditional legal scholarship. The hegemony of the 'black letter' tradition, which depends on an identified and applied body of self-referential rules, has long resisted a contextual or critical approach to the law. ${ }^{21}$ With its conventional positioning as an authoritative and universalising discourse, law was traditionally viewed as easily delineated - a 'given' - or as a reification of an absolute quantity. It was viewed as a tool whose technical, formal, and dispassionate character rigorously excludes all 'non-legal' materials and whose success is measured primarily by the concepts of certainty, objectivity, and generality, thereby always representing the 'real'. ${ }^{22}$ Yet, the emergence of the law and literature movement in the 1980s began what is now seen as a significant move towards a more contextual approach in order to demonstrate how 'law's authority, truth value, and positivism are all problematic'. ${ }^{23}$ As a result, scholars have persisted in looking beyond traditional accounts of law to better understand the various ways in which law can be better perceived, critiqued, and understood. This has meant that greater attention has been paid to the cultural forces that are implicated in meaning-making generally; and in addition to literature and screen studies, the intersection of law and social media has quickly become an expanding research interest as one of those cultural forms.

Credit is given to White's early work ${ }^{24}$ for promoting an interdisciplinary expansion of legal scholarship, and for introducing a rich variety of

20 Sara L Knox and Cristyn Davies, 'The Force of Meaning: Cultural Studies of Law' (2013) 27 Cultural Studies 1, 1. It is argued that anthropologists, social scientists, literary scholars and historians for example have engaged with tensions surrounding formal/informal justice, legal pluralism and the efficacy of normative systems. See ibid; and Julie Stone Peters, 'Law, Literature, and the Vanishing Real: On the Future of an Interdisciplinary Illusion' (2005) 120 PMLA 442 for discussions around the development of the cultural turn for law.

${ }^{21}$ Steve Greenfield, Guy Osborn and Peter Robson, Film and the Law (Cavendish Publishing 2001) 2-3.

22 Stanley Fish, 'The Law Wishes to Have a Formal Existence' in There's No Such Thing as Free Speech: And It's a Good Thing, Too (Oxford University Press 1993) 142-3.

23 Greta Olson, 'De-Americanizing Law-and-Literature Narratives: Opening up the Story' (2010) 22 Law \& Literature 338, 350.

24 James Boyd White, The Legal Imagination (University of Chicago Press 1985); James Boyd White, Heracles' Bow: Essays on the Rhetoric and Poetics of the Law (University of Wisconsin Press 1985). 
associations between the legal and the cultural to call into question the nature of law as an autonomous discipline. ${ }^{25}$ In questioning the absolute nature of law, the law and literature movement advocated the interdisciplinary utility of interpretation and many scholars became convinced that it was worthwhile to explore culture more broadly. ${ }^{26}$ In recognising that culture is the condition through which meaning is made possible, law can, and should, be treated as an active cultural reality, ${ }^{27}$ where the focus is on meaning and on the way people make sense of their lives. It is in this sense that law and culture can be viewed as mutually constitutive, ${ }^{28}$ and it is this acknowledgment that forms the heart of cultural legal studies.

As a diverse field of 'humanist and interdisciplinary scholarship', ${ }^{29}$ cultural legal studies has developed in comparatively recent times by scholars connected through a desire to explore the meaning and representation of law within a variety of cultural contexts. ${ }^{30}$ As a body of scholarship it recognises that law is inseparable from the interests,

25 David A Black, Law in Film: Resonance and Representation (University of Illinois Press 1999) 110; Margaret Thornton, Romancing the Tomes: Popular Culture, Law and Feminism (Routledge-Cavendish 2002) 10.

26 By treating the boundaries between the legal and social as flexible and somewhat porous, it is easy to recognise the myth of legal autonomy - that is, the 'fiction' that law can only be explained or interpreted by reference to the internal. Margaret Thornton, Romancing the Tomes: Popular Culture, Law and Feminism (Routledge-Cavendish 2002) 18.

27 Clifford Geertz, Local Knowledge: Further Essays in Interpretive Anthropology (Basic Books 1983) 184, 218, 232.

28 Rosemary Coombe, in 2001 and again in 2005, suggests that we not 'reify' law as an absolute quantity but treat it as culture. Rosemary Coombe, 'Is there a Cultural Studies of Law?' in Toby Miller (ed), A Companion to Cultural Studies (Wiley-Blackwell 2005) 36, quoted in Greta Olson, 'Futures of Law and Literature: A Preliminary Overview from a Culturalist Perspective' in Christian Hiebaum, Susanne Knaller and Doris Pichler (eds), Law and Literature In-Between: Contemporary Inter- and Transdisciplinary Approaches (Transcript Verlag 2015) 45.

29 Cassandra Sharp and Marett Leiboff (eds), Cultural Legal Studies: Law's Popular Cultures and the Metamorphosis of Law (Routledge 2016).

30 See recent explorations of the field in which it is explicitly named and claimed: Cassandra Sharp and Marett Leiboff (eds), Cultural Legal Studies: Law's Popular Cultures and the Metamorphosis of Law (Routledge 2016); Timothy Peters and Karen Crawley (eds), Envisioning Legality: Law, Culture and Representation (Routledge 2018), etc. 
goals, and understandings that deeply shape or comprise social life', ${ }^{31}$ and therefore deploys varied methods in order to provoke questions of how representations, narratives, and affect signify and animate normative worlds. ${ }^{32}$ To be invested in understanding law better is to approach 'culture' as encompassing all social and political institutions and practices, with meaning as an expression of those practices. It is a constructivist approach that explains how knowledge is assembled through culturally embedded practices and diversity in both representation and interpretation. As a distinct recognition that culture is processual, performative, and dynamic, ${ }^{33}$ cultural legal studies is concerned with the various ways in which legal meaning is not only constructed, but also transformed and appreciable within a public consciousness. ${ }^{34}$ Studying law's cultural interactions deepens our attention and our critique and provides a social record of the human experience of law. ${ }^{35}$

To participate in cultural legal studies research then, is to approach it as both an opportunity to critically explore the production and transformation of attitudes, values, and norms, which characterise and define the law; and as a means by which we can illuminate a cultural legal imaginary. Going beyond the focus on representation that characterised early work in law and literature studies, cultural legal studies advocates the interpretive fluidity of meaning-making within the public legal imaginary, and promotes a more explicit leaning towards consciousness as a mode of operationalising legality itself. As deployed in this book, it has meant that the analytic gaze is not limited to simply what is articulated in tweets (although this is important), but that it also extends to the deeply imbricated accounts of legality actively deployed by individuals and groups within these meaning-making practices. In the language of White:

31 Austin Sarat and Thomas R Kearns, Law in the Domains of Culture (University of Michigan Press 1998) 6.

32 Cassandra Sharp and Marett Leiboff (eds), Cultural Legal Studies: Law's Popular Cultures and the Metamorphosis of Law (Routledge 2016); see also Timothy Peters and Karen Crawley (eds), Envisioning Legality: Law, Culture and Representation (Routledge 2018) 2.

33 Lois Presser, 'Criminology and the Narrative Turn' (2016) 12 Crime Media Culture 137, 145.

34 Lieve Gies, 'The Media and Public Understanding of the Law' in Steve Greenfield and Guy Osborn (eds), Readings in Law and Popular Culture (Routledge-Cavendish 2008) 75.

35 Maria Aristodemou, Law and Literature (Oxford University Press 2000); Melanie Williams, Empty Justice (Routledge Cavendish 2002). 
'We are makers of texts and re-makers of culture. ${ }^{36}$ For him, there is an intimate connection between how we conceive legal meaning and the practice of everyday living, whereby the raw material of life 'of the actual experiences of people and the thousands of ways they can be talked about - is converted into stories that claim to tell the truth in legal terms' ${ }^{37}$

Cultural legal studies then, as both theory and method, proffers enormous potential for engendering reflexive and theoretical possibilities that were long resisted by traditional legal orthodoxies. To put it another way, cultural legal studies is a form of critique that exposes and visibilises the productive tension between the formalist aspects of law, and the complicated, nuanced, and personalised lived experience of legality. ${ }^{38}$ This research was designed to approach social media in this more contextual sense as a means of providing a link between that which is cultural, legal, emotional, and storied. As will be illustrated through the analysis presented in this book, an enquiry into a hashtag jurisprudence provides one way of challenging the conventional jurisprudential theory that boundaries and demarcation are necessary for the stability and legitimacy of law. ${ }^{39}$

\section{A Jurisprudential Raison d'être - the Hashtag as Law}

To be concerned with jurisprudence is to consider law from theoretical and philosophical perspectives. As Leiboff suggests, it is to ask 'foundational questions about law, from the nature of law itself to obligations that

36 James Boyd White, The Legal Imagination: Studies in the Nature of Legal Thought and Expression (Little, Brown \& Co 1973) 106.

37 Ibid 859.

38 See further Jennifer Travis, 'The Trials of Law and Literature' (2009) 21 American Literary History 345, 347, quoted in Greta Olson, 'Futures of Law and Literature: A Preliminary Overview from a Culturalist Perspective' in Christian Hiebaum, Susanne Knaller and Doris Pichler (eds), Law and Literature In-Between: Contemporary Inter-and Transdisciplinary Approaches (Transcript Verlag 2015) 46.

39 See Jerry Leonard (ed), Legal Studies as Cultural Studies: A Reader in (Post)Modern Critical Theory (State University of New York Press 1995); James Boyd White, Acts of Hope: Creating Authority in Literature, Law and Politics (University of Chicago Press 1994). See also Linda Myrsiades, 'Legal Studies as Cultural Studies: A Reader in (Post)Modern Critical Theory (Book Review)' (1996) 23(1) College Literature 204. 
individuals have towards law', ${ }^{40}$ and to aspire towards a deeper understanding of the nature of law within the larger political and social situation in which it exists. ${ }^{41}$ Within the field of cultural legal studies, a diverse range of critical approaches have emerged that recognise the hermeneutic potential of jurisprudence. For example, MacNeil has consistently argued for the significant utility in 'reading' popular cultural and literary texts 'jurisprudentially' in order to question important juridico-political issues of our day. ${ }^{42}$ As MacNeil demonstrates through his jurisprudential readings, when we critique cultural texts, we do not simply 'unmask' law and its inherent narratives, ${ }^{43}$ but we also uncover 'a critical theorisation of law, legality and justice'. ${ }^{44}$ It is this double movement of constitution and critique, or confirmation and contestation within a public imaginary and an experience of law, with which contemporary critical jurisprudences seek to engage. Examples such as Leiboff's theatrical jurisprudence, ${ }^{45}$ Barr's jurisprudence of movement, ${ }^{46}$ Parker's acoustic jurisprudence, ${ }^{47}$ and Peters' theological jurisprudence ${ }^{48}$ demonstrate an active exploration that is 'not in the tradition of philosophy or theory, but as a practice that guides and shapes understanding of foundational concepts and ideals in law'. ${ }^{49} \mathrm{~A}$ hashtag jurisprudence takes up this call to interrogate the cultural conditions that shape not only our perceptions of law, but also the very composition of law itself. As I have noted elsewhere with Leiboff,

40 Marett Leiboff, Towards a Theatrical Jurisprudence (Routledge 2019) xvi.

41 Ibid.

42 William P MacNeil, Lex Populi: The Jurisprudence of Popular Culture (Stanford University Press 2007) 157.

43 Ibid 10, quoted in Timothy Peters and Karen Crawley (eds), Envisioning Legality: Law, Culture and Representation (Routledge 2018) 4.

44 Timothy Peters, Theological Jurisprudence of Popular Cinema: Superheroes, Science Fictions and Fantasies of Modern Law (Edinburgh University Press 2019) 25.

${ }_{45}$ Marett Leiboff, Towards a Theatrical Jurisprudence (Routledge 2019).

46 Olivia Barr, Jurisprudence of Movement; Common Law, Walking, Unsettling Place (Routledge 2016).

47 James Parker, Acoustic Jurisprudence: Listening to the Trial of Simon Bikindi (Oxford University Press 2015).

48 Timothy Peters, Theological Jurisprudence of Popular Cinema: Superheroes, Science Fictions and Fantasies of Modern Law (Edinburgh University Press 2019).

49 MarettLeiboff, Towards a TheatricalJurisprudence(Routledge2019)xi. For yet another alternative jurisprudence, see Andreas Philippopoulos-Mihalopoulos, Spatial Justice: Body Lawscape, Atmosphere (Routledge 2015). 
cultural legal studies recognises the complex encounters between culture and law as a living and active jurisprudence, and to be specific, 'as a means through which to think about how to do law well'.$^{50}$

With the expansion of readily accessible platforms of social media production, consumption, and engagement, this book adopts a hashtag jurisprudence as a way of altering ideas about how legal meanings are made, circulated, and construed..$^{51}$ In doing so, it facilitates a movement towards doing law effectively. The research presented in this book not only explores the role of narrative in the emergence of cultural legal phenomena, but also demonstrates the role that social media narratives play in the visibility of legality. As will be shown in the next section, narratives frame, contextualise, and reassert normative values and expectations of the law; and as such, this book seeks to demonstrate that social media platforms can (and do) facilitate the constitution, transformation, and propagation of legality.

\section{The Constitutive Role of Narrative in Law}

Narratives and stories are essential to the human experience ${ }^{52}-$ to the ways we communicate, learn, and reflectively make sense of the world. ${ }^{53}$ Narratives are the medium through which persuasion is enacted, and through which critique of societal practices and processes occur. In my research I recognise that 'identification with a narrative brings passion

50 Cassandra Sharp and Marett Leiboff (eds), Cultural Legal Studies: Law's Popular Cultures and the Metamorphosis of Law (Routledge 2016) 6.

${ }_{51}$ Richard K Sherwin, Neal Feingenson and Christina Spiesel, 'Law in the Digital Age: How Visual Communication Technologies are Transforming the Practice, Theory, and Teaching of Law' (2006) 12(2) Boston University Journal of Science \& Technology Law 227, 266: The 'study of law as a constitutive rhetoric must now encompass the various ways in which this digital capacity affects the legal meaning-making process'.

52 That narrative is fundamental to human understanding and self-identity can be further explored in the seminal work of Jerome Bruner. See for example: Jerome Bruner, Making Stories: Law, Literature, Life (Harvard University Press 2002) and Jerome Bruner, 'Life as Narrative' (1987) 54 Social Research 11.

53 'Narratives' contain agents with human-like subjectivity, involve changes or a description of human-like experience, and take place in some identifiable space and time. 'Discourse', in turn, describes the form of the narrative, including the perspective from which the story is told. 
and meaning to it' ${ }^{54}$ Narrative has long played a significant role in social science scholarship with the predominant assumption that "creating and interpreting narratives is universal'. ${ }^{55}$ Narratives enable the construction of 'an ordered reality where individuals are portrayed as law-abiding or law-breaking, the world as safe or dangerous, as governed by law or violence, and the legal system as effective or not ${ }^{36}$ and they allow us to reflect upon the way life should or could be. As will be explored in this chapter and Chapter 2, narratives represent fluid cultural interpretations of events. Examined through a legal lens, they enable us to reflect on, question, and shape foundational legal assumptions upon which our legal system has been legitimised and authorised. ${ }^{57}$ In the digital age, social media platforms like Twitter and Facebook provide an opportunity for individuals to listen, interpret, and tell their stories immediately, accessibly, and interactively. Indeed, it is the aggregate of these individual stories on social media that shapes collective narratives that, in turn, impact on our common understandings of law. This book therefore places an underlying emphasis on the narrativity of a law and social media enquiry, and proceeds on the basis that it is through everyday stories that perceptions of law and justice are formed and maintained. ${ }^{58}$

54 Hugh T Miller, 'Narrative Subscription in Public Policy Discourse' (2019) 13 Critical Policy Studies 241, 243.

55 Greta Olson, 'Futures of Law and Literature: A Preliminary Overview from a Culturalist Perspective' in Christian Hiebaum, Susanne Knaller and Doris Pichler (eds), Law and Literature In-Between: Contemporary Inter- and Transdisciplinary Approaches (Transcript Verlag 2015) 42.

56 Timothy O Lenz, Changing Images of Law in Film \& Television (Peter Lang Inc., International Academic Publishers 2003) 11.

57 Greta Olson, 'Futures of Law and Literature: A Preliminary Overview from a Culturalist Perspective' in Christian Hiebaum, Susanne Knaller and Doris Pichler (eds), Law and Literature In-Between: Contemporary Inter- and Transdisciplinary Approaches (Transcript Verlag 2015) 43.

58 Lieve Gies, 'The Media and Public Understanding of the Law' in Steve Greenfield and Guy Osborn (eds), Readings in Law and Popular Culture (Routledge-Cavendish 2008) 74. Cultural legal studies adopts this focus, seeking to go beyond appellate case law, statutory interpretation, and social policy, the dominant topics of law teaching and academic writing, in order to more broadly encompass legal meaning-making practices throughout society: Richard K Sherwin, Neal Feingenson and Christina Spiesel, 'Law in the Digital Age: How Visual Communication Technologies are Transforming the Practice, Theory, and Teaching of Law' (2006) 12(2) Boston University Journal of Science \& Technology Law 227, 259. 
To recognise the importance of narrative within law is to give voice to the human and subjective, and to view the interpretation of law as an ongoing social dialogue, rather than just the product of specialised institutions. ${ }^{59}$ In her important work on the narrativity of law, Olson argues that '[1]aw is always embedded in cultural practices that at least in part have a narrative component. Narratives and images of law then inform attitudes about legal systems and legal cultures, and these images and topoi are culturally specific. ${ }^{60}$

I have argued previously that individuals use stories to frame and contextualise normative expectations of the legal system, ${ }^{61}$ and in so doing, they concomitantly participate in law's constitution. This is one aspect of what Cover conceptualised in his idea of the 'nomos', a cultural world of law that includes what people believe law is, and the stories they tell about it. ${ }^{62}$ In this way, the nomos can be viewed as the narratives that help to legitimise law and bring it into being as something meaningful. The nomos can only be understood in the context of the narratives that substantiate and give it meaning, and so to understand the world of law we must begin to appreciate how individuals conceive of and construct meaning about the law through stories. ${ }^{63}$ To explore the way that social media narratives reflect, contain, critique, and transform meanings about

59 Timothy Peters and Karen Crawley (eds), Envisioning Legality: Law, Culture and Representation (Routledge 2018) 7; Peter Goodrich, Oedipus Lex: Psychoanalysis, History, Law (University of California Press 1995); Austin Sarat, Matthew Anderson and Cathrine O Frank (eds), Law and the Humanities: An Introduction (Cambridge University Press 2010); Richard K Sherwin, When Law Goes Pop: The Vanishing Line between Law and Popular Culture (University of Chicago Press 2000).

60 Greta Olson, 'Futures of Law and Literature: A Preliminary Overview from a Culturalist Perspective' in Christian Hiebaum, Susanne Knaller and Doris Pichler (eds), Law and Literature In-Between: Contemporary Inter- and Transdisciplinary Approaches (Transcript Verlag 2015) 57.

${ }_{61}$ Cassandra Sharp, “"Represent a Murderer ... I'd Never do That!” How Students use Stories to Link Ethical Development and Identity Construction' in Michael Robertson and others (eds), The Ethics Project in Legal Education (Routledge 2011) 33; Cassandra Sharp, "The "Extreme Makeover" Effect of Law School: Students being Transformed by Stories' (2005) 12(1) Texas Wesleyan Law Review 233.

${ }^{62}$ Robert M Cover, 'The Supreme Court 1982 Term - Foreword: Nomos and Narrative' (1983) 97 Harvard Law Review 4.

63 Ibid 5. 
legality, is to recognise that individuals are both carriers of, and contributors to, differentiated aspects of the nomos.

\section{SOCIAL MEDIA AS PART OF AN ACTIVE CULTURAL REALITY}

While a study of social media is now firmly an established area of academic analysis for most social science disciplines, and despite the embeddedness of social media in 'everyday social and communicative interactions', ${ }^{64}$ the exploration of law as expressed and constituted in social media has not been so readily undertaken. Yet, because participatory media affords citizens the power to 'raise their voice, challenge institutional authority, and express emotion' ${ }^{65}$ it is crucial to recognise and rethink the legal in the 'spaces and sense of the previously hidden', and explicitly call attention to the 'seachange in the mode of law's presence'. ${ }^{66}$ Delage, Goodrich and Wan, in their introduction to Law and New Media: West of Everything, classify this seachange as 'post-law'. Post-law is a 'law unbound, free of its former thresholds, relocated and in the process of reinvention' ${ }^{67}$ In this sense, a tweet or retweet is post-law, a Facebook comment is post-law, and a hashtag collects, and significantly, narrativises them to facilitate shared emotions, ideas, and values. Post-law envisages the 'ever-present need for a dormant legality to reinvent itself as collective thought embedded in and contributing to quotidian modes' of life. ${ }^{68}$ The hashtag, the tweet, the like button - these are modes and methods that represent a 'remediation of legality by virtue of the move to the virtual and by dint of the novelty of the digital media, $\ldots$ and its variable capacities' ${ }^{9}{ }^{69}$ It is this remediation of legality through social media activity that values the ontological implications of digital

64 Katrin Weller and others, Twitter and Society (Peter Lang Inc. 2014).

65 Sue Robinson, "'Journalism as a Process": The Organizational Implications of Participatory Online News' (2011) 13 Journalism \& Communication Monographs 137, 149, quoted in Jeffrey Layne Blevins and others, 'Tweeting for Social Justice in \#Ferguson: Affective Discourse in Twitter Hashtags' (2019) 21 New Media \& Society 1636, 1637.

66 Christian Delage, Peter Goodrich and Marco Wan, 'Introduction: West of Everything' in Christian Delage, Peter Goodrich and Marco Wan (eds), Law and New Media West of Everything (Edinburgh University Press 2019) 1.

67 Ibid 2.

68 Ibid 23.

69 Ibid 16. 
practices through which law is relayed..$^{70}$ Legality, just like our social world, is deeply mediatised, ${ }^{71}$ and as a complex site of encounter between contemporary culture and law, social media provides access to informally articulated, and constituted, legality.

This book therefore proceeds on the footing that, rather than simply influencing individuals, social media allows for an active agency in transforming and producing understandings and attitudes through personal interactions. Indeed, scholarship surrounding Twitter usage has pointed to the importance of studying 'more everyday user practices, in order to document more fully the lived experience of using the platform', ${ }^{72}$ and that the communication of Twitter (while often misunderstood and/or dismissed) is 'indeed deeply meaningful (if highly phatic and ephemeral)' ${ }^{73}$ As such, this book stands in contrast to the established quantitative sentiment analysis tradition that measures emotional responses in social media on a statistical scale. As will be described in Chapter 3, the book does so by favouring in-depth qualitative methodologies that interrogate the expression and use of emotions through comments in the digital sphere.

Research concerning the varied uses of social media have been proliferating across the social science disciplines, to provide perspectives around public interpretation and involvement in social issues and events. From studies of communal sense-making in relation to crisis communication,${ }^{74}$ to projects that investigate the amplification of less powerful

70 Heather A Horst and Daniel Miller (eds), Digital Anthropology (Berg Publications 2012); Christian Delage, Peter Goodrich and Marco Wan, 'Introduction: West of Everything' in Christian Delage, Peter Goodrich and Marco Wan (eds), Law and New Media West of Everything (Edinburgh University Press 2019) 8. On mobile ontology, see Maurizio Ferraris, Where Are You? (Fordham University Press 2014).

71 Nick Couldry and Andreas Hepp, The Mediated Construction of Reality (Polity Press 2017) 30: '[a]s a result, the ways in which we make sense of the world phenomenologically become necessarily entangled with the constraints, affordances and power-relations that are features of media as infrastructures for communication'.

72 Axel Bruns and Katrin Weller, 'Twitter as a First Draft of the Present - and the Challenges of Preserving It for the Future' (8th ACM Conference on Web Science, Hannover, Germany, May 2016) 183, 184.

73 Ibid.

74 Frances Shaw and others, 'Sharing News, Making Sense, Saying Thanks: Patterns of Talk on Twitter during the Queensland Floods' (2013) 40(1) Australian Journal of Communication 23. 
voices on social media in the pursuit of social justice, ${ }^{75}$ many scholars have undertaken research concerning public collective responses to key events through social media. ${ }^{76}$ Bruns and Burgess, for example, conducted studies around the use of Twitter hashtags in the Christchurch earthquakes and Queensland (Australia) floods, and found that the specific communicative affordances of Twitter during disasters fulfils a significant mediating and coordinating function for crisis management. ${ }^{77}$ Bruns and Burgess have further argued that hashtags facilitate the easy formation of 'ad hoc' communities, to unite and bond large numbers of users that would otherwise be unconnected. ${ }^{78}$ Work within this context has highlighted and exposed the utilisation of hashtags as provocateur in key political discussions, social controversies, and trending topics. For example, studies have been conducted that analysed the role of social media in the election of two former presidents of the United States (Donald Trump ${ }^{79}$ and Barrack Obama ${ }^{80}$ ); climate change; ${ }^{81}$ Australian

75 See examples described in Jeffrey Layne Blevin and others, 'Tweeting for Social Justice in \#Ferguson: Affective Discourse in Twitter Hashtags' (2019) 21 New Media \& Society 1636.

76 For example, during the 2010 Haiti earthquake individuals used Twitter to connect with a community of supporters, to promote involvement and to personalise issues: Brian G Smith, 'Socially Distributing Public Relations: Twitter, Haiti and Interactivity in Social Media' (2010) 36 Public Relations Review 329, 331.

Axel Bruns and Jean Burgess, 'Crisis Communication in Natural Disasters: The Queensland Floods and Christchurch Earthquakes' in Katrin Weller and others (eds), Twitter and Society (Peter Lang 2014).

78 Axel Bruns and Jean Burgess, 'The Use of Twitter Hashtags in the Formation of Ad Hoc Publics' (6th European Consortium for Political Research General Conference, University of Iceland, Reykjavik, August 2011). This concept will be further discussed in Chapter 2.

79 Panayota Gounari, 'Authoritarianism, Discourse and Social Media: Trump as the "American Agitator"' in Jeremiah Morelock (ed), Critical Theory and Authoritarian Populism (University of Westminster Press 2018).

${ }^{80}$ Lize-Marie Smuts, 'Social Networking Sites as a New Public Sphere: Facebook and its Potential to Facilitate Public Opinion as the Function of Public Discourse - A Case Study of the 2008 Obama Campaign' (MPhil Thesis, Stellenbosch University 2010).

81 Julie Uldam and Tina Askanius, 'Online Civic Cultures: Debating Climate Change Activism on YouTube' (2013) 7 International Journal of Communication 1185; Alexandra Segerberg and W Lance Bennett, 'Social Media and the Organization of Collective Action: Using Twitter to Explore the Ecologies of Two Climate Change Protests' (2011) 14 The Communication Review 197. 
Government leadership spills; $;{ }^{82}$ Wikileaks; ${ }^{83}$ celebrity news; ${ }^{84}$ and most recently, cancel culture. ${ }^{85}$ Research has also been conducted into the role of social media in constructing meaning as a direct response to crime. In particular, several studies have demonstrated that social media posting intersects with, and amplifies, criminal justice narratives. For example, Zappavigna analysed the use of Twitter hashtags in response to the parole of Australian Schapelle Corby, ${ }^{86}$ while Salter has examined online abuse and justice-seeking on social media in relation to gender and crime. ${ }^{87}$ Tubridy has also conducted a wide-ranging Facebook case study of the 'signal crime' murder of Australian Jill Meagher, in which she demonstrates that social media can both perpetuate and contest traditional 'law and order' discourses. ${ }^{88}$

Clearly, there is no shortage of topics, issues, and events that can be mediated and discussed on social media. But rather than taking for granted that 'social media content represents either a reflection of public opinion, the sharing of information or factual news reporting on crime

82 See for example: Axel Bruns and Jean Burgess, '\#Ausvotes: How Twitter Covered the 2010 Australian Federal Election' (2011) 44 Communication, Politics \& Culture 37.

83 Flew and Liu analysed the Australian media's reaction to WikiLeaks: Terry Flew and Bonnie Rui Liu, 'Globally Networked Public Spheres? The Australian Media Reaction to WikiLeaks' (2011) 5(1) Global Media Journal: Australian Edition 1.

84 Jean Burgess, Peta Mitchell and Felix Victor Münch, 'Social Media Rituals: The Uses of Celebrity Death in Digital Culture' in Zizi Papacharissi (ed), A Networked Self and Birth, Life, Death (Routledge 2019).

85 See for example Gwen Bouvier, 'Racist Call-Outs and Cancel Culture on Twitter: The Limitations of the Platform's Ability to Define Issues of Social Justice' (2020) 38 Discourse, Context \& Media 1.

${ }^{86}$ Michele Zappavigna, 'Searchable Talk: The Linguistic Functions of Hashtags in Tweets about Schapelle Corby' (2015) 9(1) Global Media Journal: Australian Edition 1, 2.

87 Michael Salter, Crime, Justice and Social Media (Routledge 2016) 4.

88 Kate Tubridy, "So the Justice System Was to Blame Yet Again": Discourses of Betrayal and Retribution on Facebook' (2018) 22 Media and Arts Law Review 382; and Kate Tubridy, 'Facebook and a Fair Trial: Caution, Challenge and Contradiction' (2020) 2(1) Law, Technology and Humans 135. Powell, Overington, and Hamilton in studying the same subject, likewise found that social media perpetuates traditional narratives of crime: Anastasia Powell, Caitlin Overington and Gemma Hamilton, 'Following \#JillMeagher: Collective Meaning-Making in Response to Crime Events via Social Media' (2017) 14 Crime Media Culture 409, 424. 
events', ${ }^{89}$ the collective narration and meaning-making in response to events can be provocatively political. Indeed, they can even be revolutionary. The significant power that social media commentary can have on the mobilisation of collective activism has been evident in many studies related to social justice issues. Take for example Harlow's research into an online justice movement in Guatemala in $2009 ; 9^{90}$ or the protests in Iran following elections in the same year that were labelled as a 'Twitter Revolution'. ${ }^{91}$ Other work followed, including the comprehensive project by Howard et al. into the Arab Spring revolution of $2011 ; ;^{92}$ the study in Australia examining the use of social media in Indigenous activism; ${ }^{93}$ and the study from Gerbaudo into the Occupy Wall Street movement in $2011 .{ }^{94}$ Each of these studies demonstrated the capacity for social media to participate effectively in generating groundswell for uniting individuals towards a cause, and particularly for consequent offline activism.

More recently, political and social issues as divisive as race and gender have also played out over social media through the hashtag mechanism. With \#blacklivesmatter and \#metoo amplifying public criticism of police brutality and workplace sexual harassment respectively, the dynamic and widespread impact of social media was illustrated in stark detail. The social and political significance of these hashtags continue to reverberate around the globe, and it is clear that social media is an extremely powerful site for facilitating the expression of previously ignored voices. Of course, it is also important to acknowledge that there is much disagreement in the scholarship over how positive or even effective

89 Most recently, Powell, Overington and Hamilton (ibid) considered the collective practices of meaning-making, and in particular, the representations of sexual assault and gendered issues in the Twitter responses to the murder of Ms Meagher through narrative criminology.

90 Summer Harlow, 'Social Media and Social Movements: Facebook and an Online Guatemalan Justice Movement that Moved Offline' (2011) 14 New Media \& Society 225 .

91 Christian Christensen, 'Discourses of Technology and Liberation: State Aid to Net Activists in an Era of "Twitter Revolutions"" (2011) 14 The Communication Review 233, 233-8.

92 See Manuel Castells, Networks of Outrage and Hope: Social Movements in the Internet Age (Polity Press 2012).

93 Theresa Lynn Petray, 'Protest 2.0: Online Interactions and Aboriginal Activists' (2011) 33 Media, Culture, Society 923.

94 Paolo Gerbaudo, Tweets and the Street (Pluto Press 2012). 
democratic engagement through social media truly can be. ${ }^{95}$ The debate sees on the one hand the potential for social change, or on the other, the descent into pure 'slacktivism' forged by commercially driven entities. ${ }^{96}$ Nevertheless, while there is no denying the nature of commercial production, nor the contradictory features of social media, these platforms succeed in creating and mediating a 'new type of social capital: connectivity' ${ }^{97}$ As will be explored in detail in Chapter 2, it is indeed the combination of the catalysing event, emotional antiphons, and the affordances of a hashtag, that enables ad hoc publics to coalesce around particular narratives. Papacharissi refers to the formation of 'affective publics' as that which facilitates such collaborative narratives to be formed ${ }^{98}$ and Zappavigna's concept of 'ambient affiliation' provides further context to the ways in which individuals connect with one another in response to key events. ${ }^{99}$ In Chapters 2 and 3, we will see how viewing Twitter as a platform for ambient affective connection is key to the identification and observance of a hashtag jurisprudence that both engages and resists narratives of legality. The next section of this chapter demonstrates how the social impact of terrorism, or more pointedly, the threat of terrorism, fuels community engagement on social media; and significantly how terrorism serves as an illustrative example of hashtag jurisprudence.

95 See for example the competing positions of Clara Crivellaro and others, 'A Pool of Dreams: Facebook, Politics and the Emergence of a Social Movement' (Human Factors in Computing Conference, Toronto, Canada 2014); Evgeny Morozov, The Net Delusion: The Dark Side of Internet Freedom (Public Affairs 2011).

96 Evgeny Morozov, The Net Delusion: The Dark Side of Internet Freedom (Public Affairs 2011).

97 José van Dijck, 'Facebook and the Engineering of Connectivity: A Multi-Layered Approach to Social Media Platforms' (2013) 19 Convergence: The International Journal of Research into New Media Technologies 141.

98 Zizi Papacharissi, Affective Publics: Sentiment, Technology, and Politics (Oxford University Press 2014).

99 Michele Zappavigna, 'Ambient Affiliation: A Linguistic Perspective on Twitter' (2011) 13 New Media \& Society 788. 


\section{TERRORISM AS PART OF A HASHTAG CULTURE}

Terrorism has been one of the most prevalent security threats of the $21 \mathrm{st}$ century, affecting nations and individuals around the globe. ${ }^{100}$ As a result, much scholarship has been devoted to understanding how particular violent acts become labelled as terrorism, and to better understand the discursive conditions in which terrorism is seen either as an objective, an inherent quality residing in an act, or a subjective socio-political construction. ${ }^{101}$ In an attempt to classify and compile historical information related to global acts of terrorism, the Global Terrorism Database defines terrorism as the "use of illegal force and violence by a non-state actor to attain a political, economic, religious, or social goal through fear, coercion, or intimidation'. ${ }^{102}$ However, the media, public, and government labelling of terrorism is fraught with elusion, because it is often circumscribed and articulated through hegemonic political acts. As Derrida has stated:

We must also recognize here strategies and relations of force. The dominant power is the one that manages to impose and, thus, to legitimate, indeed, to legalize (for it is always a question of law) on a national or world stage, the terminology and thus the interpretation that best suits it in a given situation. ${ }^{103}$

Nevertheless, scholars consistently seek to overcome definitional hurdles by attempting to articulate key aspects of what constitutes terrorism. For

100 Alexandra Homolar and Pablo A Rodríguez-Merino, 'Making Sense of Terrorism: A Narrative Approach to the Study of Violent Events' (2019) 12 Critical Studies on Terrorism 561.

101 See for example: Richard Jackson, 'Unknown Knowns: The Subjugated Knowledge of Terrorism Studies' (2012) 5 Critical Studies on Terrorism 11; Alex P Schmid, 'The Definition of Terrorism' in Alex P Schmid (ed), The Routledge Handbook of Terrorism Research (Routledge 2011); Rainer Hülsse and Alexander Spencer, 'The Metaphor of Terror: Terrorism Studies and the Constructivist Turn' (2008) 39 Security Dialogue 571; Lee Jarvis, 'The Spaces and Faces of Critical Terrorism Studies' (2009) 40 Security Dialogue 5.

102 National Consortium for the Study of Terrorism and Responses to Terrorism, Global Terrorism Database Codebook (University of Maryland

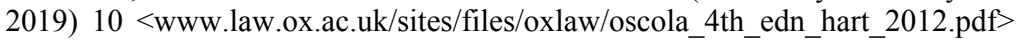
accessed 29 March 2021.

103 Jaques Derrida, 'A Conversation with Jacques Derrida' in Giovanna Borradori, Philosophy in a Time of Terror: Dialogues with Jurgen Habermas and Jacques Derrida (University of Chicago Press 2004) 105. 
example, Norris et al. suggest that terrorism should be simply understood as 'the systematic use of coercive intimidation against civilians for political goals' ${ }^{104}$ Homolar and Rodríguez-Merino have further circumscribed what they call a set of 'common-sense characteristics' of terrorism, including descriptors such as arbitrary, indiscriminate, and extraordinary violence; illegal and morally unjustifiable violence; and targeting civilians and non-combatants for political purposes. ${ }^{105} \mathrm{It}$ is interesting to note, however, that Homolar and Rodríguez-Merino posit this common sense understanding by approaching terrorism as a narrative phenomenon, whereby they argue that 'narratives foster making sense of unfamiliar material and events by presenting what is novel within a familiar code' ${ }^{106}$ The common-sense features of terrorism are integral to this familiarisation, and they serve as narrative anchors, without which these uncertain, violent and fear-inducing acts would remain unintelligible. ${ }^{107}$

Each of the case studies discussed in this book was constructed, articulated, or contested as 'terrorism' by both the media and government positioning at the time, and each contained the common-sense characteristics identified above. As the following chapters will demonstrate, the label and frame of 'terrorism' is critically connected to this categorisation through the narrativised public responses to each event. Of course, as the analysis will establish, this has flow-on effects for public expectations of appropriate policy and legal responses, such as retributive countermeasures and harsher penalties. ${ }^{108}$

With the rise in terrorism over the last couple of decades, there has been a correlative rise in scholarship surrounding the relationship of social media and terrorism. Dovetailing with the focus of this book, prior research in the social sciences has investigated the use of hashtags as a mechanism for facilitating collective sense-making follow-

104 Pippa Norris, Montague Kern and Marion Just, 'Framing Terrorism' in Pippa Norris, Montague Kern and Marion Just (eds), Framing Terrorism: The News Media, the Government and the Public (Routledge 2003) 6.

105 Alexandra Homolar and Pablo A Rodríguez-Merino, 'Making Sense of Terrorism: A Narrative Approach to the Study of Violent Events' (2019) 12 Critical Studies on Terrorism 561.

106 Ibid 563-4.

107 Ibid 564.

108 Matthew J Dolliver and Erin M Kearns, 'Is It Terrorism? Public Perceptions, Media, and Labeling the Las Vegas Shooting' [2019] Studies in Conflict \& Terrorism $<$ https://www.tandfonline.com/doi/full/10.1080/1057610X .2019.1647673> accessed 29 March 2021. 
ing human-made crisis events, including terrorism. ${ }^{109}$ These studies demonstrate that the use of Twitter, and the hashtag affordance, allows individuals to connect with others in order to make sense of horrific events. ${ }^{110}$ However within the discipline of law, scholarship surrounding social media and terrorism is largely dedicated to the furtherance of counter-terrorism policies and related socio-political strategies. Krutrök and Lindgren argue that terrorism studies have tended to focus on the political causes and the perpetrators of terrorism, or the role of social media as 'potential tools for terrorist recruitment, mobilization, and coordination', rather than to the narratives produced during these moments. ${ }^{11}$ Moreover, conventional legal research approaches to social media have primarily focused on the form and function of formal law and policy in order to combat and prevent terrorism, with the result that very little attention has been paid to analysing cultural legal responses articulated by the public during an attack. ${ }^{112}$ Following the lead of social science researchers described above, this book speaks into this nascent empirical research, ${ }^{113}$ with an exploration of the narratives that circulate through social media commentary, yet with explicit application to legality.

109 Stefan Stieglitz and others, 'Sense-Making in Social Media during Extreme Events' (2018) 26 Journal of Contingencies and Crisis Management 4; Thomas Heverin and Lisl Zach, 'Use of Microblogging for Collective Sense-Making during Violent Crises: A Study of Three Campus Shootings' (2012) 63 Journal of the American Society for Information Science and Technology 34; Moa Eriksson, 'Managing Collective Trauma on Social Media: The Role of Twitter after the 2011 Norway Attacks' (2015) 38 Media, Culture \& Society 365.

110 Diana Fischer-Preßler, Carsten Schwemmer and Kai Fischbach, 'Collective Sense-Making in Times of Crisis: Connecting Terror Management Theory with Twitter Reactions to the Berlin Terrorist Attack' (2019) 100 Computers in Human Behavior 138.

111 Moa Eriksson Krutrök and Simon Lindgren, 'Continued Contexts of Terror: Analyzing Temporal Patterns of Hashtag Co-Occurrence as Discursive Articulations' (2018) 4(4) Social Media + Society 1, 2.

112 See further Moa Eriksson Krutrök and Simon Lindgren, 'Continued Contexts of Terror: Analyzing Temporal Patterns of Hashtag Co-Occurrence as Discursive Articulations' (2018) 4(4) Social Media + Society 1.

113 Innes et al. researched Twitter and terrorism and identified that 'analysing social media affords a higher resolution and more agile way of tracking and tracing how processes of social reaction develop and evolve over time'. Martin Innes and others, 'Ten "Rs" of Social Reaction: Using Social Media to Analyse the "Post-Event" Impacts of the Murder of Lee Rigby' (2018) 30 Terrorism and Political Violence 454, 455. See also Moa Eriksson Krutrök and Simon Lindgren, 'Continued Contexts of Terror: Analyzing Temporal Patterns of 
Specifically, this book investigates the complex and interconnected emotions that are enmeshed in expectations of law as a result of terror attacks.

For this reason, the case studies probe the social media narratives at a particular moment in time for each event, and in a similar fashion to Krutrök and Lindgren, apply a cross-event analysis. ${ }^{114}$ The approach was to focus on the first 24 hours of each incident to explore what narratives or counter-narratives were constructed and framed, and to provide insight into the affective discourses that helped define those moments. As will be shown in Chapter 4, users related these events to their own lives, and framed the occurrences as 'relatable' 115 to a broader critique of safety and security in the Western world.

\section{CHAPTER OUTLINE}

This book describes an investigation of the complex, nuanced construction, transformation, and constitution of legality in public responses to terror events. The chapters progressively move through an argument that the hashtag is yet another way that legality is powerfully translated in and through our everyday lives. The tweeting of personal responses to these terror events is an example of how social media has become a vital mechanism through which the public can not only make sense of the world, but also contribute to the fabric of a hashtag jurisprudence. The following provides a general outline of each chapter as a segment in that argument.

Having introduced in this chapter social media commenting as a form of jurisprudential practice, Chapter 2 proceeds to explain the imbrication of law, culture, and narrative that is crafted when individuals respond to events on social media platforms, and identifies how it is possible for

Hashtag Co-Occurrence as Discursive Articulations' (2018) 4(4) Social Media + Society 1.

114 Krutrök and Lindgren found that: 'Most research in this area has been focused on single terrorist acts that have limited generalization. ... More specifically [the study] ... directs its interest toward how previous and current terror events are understood through, and in relation to, each other through a process of articulation ... [and] the co-use of their related hashtags.' Moa Eriksson Krutrök and Simon Lindgren, 'Continued Contexts of Terror: Analyzing Temporal Patterns of Hashtag Co-Occurrence as Discursive Articulations' (2018) 4(4) Social Media + Society 1, 2.

115 Jeffrey Layne Blevins and others, 'Tweeting for Social Justice in \#Ferguson: Affective Discourse in Twitter Hashtags' (2019) 21 New Media \& Society 1636, 1637. 
narratives to be constructed and curated from the social media hashtag milieu. To use or add a hashtag to a social media comment has a function much greater than simple categorisation. It is to inscribe affiliation with a 'co-present, impermanent community by bonding around evolving topics of interest'. ${ }^{116}$ This medium of expressing personal evaluation to a large ambient and dynamic audience facilitates the identification of narratives of communal responses in real time to key events. Chapter 2 introduces the argument that social media narratives are therefore a useful tool for evaluating and critiquing law as deeply constituted in culture, and suggests that not only is legal meaning constructed and transformed by social media narratives, but that the aggregate of individual comments on social media helps to shape (and impacts upon) forms of legality.

A project like the one undertaken for this book necessitates an active engagement with interdisciplinarity. Although Fish once declared that the 'impossibility of authentic critique is the impossibility of the interdisciplinary project', ${ }^{117}$ this book employs an argument drawn from Geertz that the 'blurred genres' of interdisciplinarity provide an opportunity for cultural maps to be redrawn. ${ }^{118}$ More than merely using one discipline to illuminate another, or simply building bridges between the two, ${ }^{119}$ the use of interdisciplinary methods in this book can be seen to be more like restructuring or transforming knowledge. For this reason, Chapter 3 takes the time to outline the key methodological features drawn from cultural studies, linguistics, and framing theory that are integrated to maximise insight from social media about the public perception of law in contemporary life. In doing so, this chapter explains the need for an interdisciplinary methodology that is concerned to contextualise law within wider cultural processes and to shine light on the ambiguities, uncertainties, and contradictions inherent within both law and social media narratives. The chapter also provides descriptions of the methods used for coding, analysing, and interpreting individual comments within the hashtags of

116 Michele Zappavigna, 'Ambient Affiliation: A Linguistic Perspective on Twitter' (2011) 13 New Media and Society 788, 790, 800.

117 Stanley Fish, There's No Such Thing as Free Speech: And It's a Good Thing, Too (Oxford University Press 1993) 242.

118 Clifford Geertz, Local Knowledge: Further Essays in Interpretive Anthropology (Basic Books 1983).

119 Linda Myrsiades, 'Legal Studies as Cultural Studies: A Reader in (Post) Modern Critical Theory (Book Review)’ (1996) 23(1) College Literature 204. 
the five case studies used, including: data collection; in-depth thematic content analysis; and critical discourse analysis.

Chapter 4 moves to illuminate how patterns of social reaction on social media are nuanced, complicated, and divergent among the public in relation to the framing of terrorism and of the rule of law across the world. Observing the occurrence of frequent multiple terror attacks across the Western world in recent years has positioned individuals and communities to be in a constant state of alert, and the seemingly regular occurrence of terrorism reframes possibility into inevitability. Such resignation about the status of living in a contemporary culture where terrorism is perceived as an oxymoronic inevitable possibility, easily contributes to a narrative of fear, doubt, and uncertainty, and it impliedly operationalises an underlying personal and plural frame within which institutions of law are expected to protect citizens and provide security. The sheer volume of communication on social media allows different communities to frame alternative interpretations of and responses to the same event. ${ }^{120}$ For this reason, Chapter 4 collates and analyses narratives as they have developed in response to the case studies, and addresses the deployment of the terror frame through which individuals implicitly reinforce a 'just worldview'. Of significance, the chapter will demonstrate that the articulation of emotional responses to these events as they happened, produced a particular Westernised collective narrative that frames identity around perceptions of justice.

As Chapter 4 demonstrates, individuals place a high importance on 'just world' desires and create normative expectations of the law to provide security and promote justice. As a result of this worldview, Lerner has argued that individuals will engage in various cognitive and behavioural 'strategies' or 'tactics' to make sense of injustice around them and maintain a belief in justice in response to a threat. ${ }^{121}$ Chapter 5 therefore focuses on highlighting two related strategies evident in the

120 Martin Innes and others, From Minutes to Months: A Rapid Evidence Assessment of the Impact of Media and Social Media during and after Terror Events (Crime and Security Research Institute, July 2018) <https:// crimeandsecurity.org/feed/minutestomonths> accessed 4 July 2021.

121 Melvin J Lerner, The Belief in a Just World: A Fundamental Delusion (Plenum Press 1980), as discussed in John H Ellard, Annelie Harvey and Mitchell J Callan, 'The Justice Motive: History, Theory, and Research' in Clara Sabbagh and Manfred Schmitt (eds), Handbook of Social Justice Theory and Research (Springer 2016) 131. 
case studies: (i) the adoption of an 'ultimate justice' perspective; and (ii) the movement towards solidarity and national unity. Events like terror attacks bring into sharp focus the precarious nature of human existence, and this chapter taps into contemporary collective notions of how to approach the future, and where to put one's trust. To join in resisting fear is to actively become unified against a common enemy, and the repetition of certain images and phrases that position terrorism as 'injustice' also works to encourage others to join the fight against it. Take for example the unifying trends of these hashtags: \#WEARElondONErs in response to the London attacks, and \#illridewithyou in response to the Sydney Siege in Australia. These conscious identifications in solidarity with fellow citizens are emotional appeals that demonstrate a unified investment in securing safety, and are deployed as a way of re-inscribing communities against fear. This chapter explores the impact of hashtagging as a dynamic emergent activity that can confirm or question communal trust in national legal institutions, and that reflects manifestations of socio-political activity.

In the (re)telling of events and stories through hashtags, individuals cannot help but verbalise and render apparent what Sherwin argues are the often-unacknowledged emotions, desires, and conflicting impulses that circulate within the law. ${ }^{122}$ Indeed, it is not the content or text that often causes a tweet to become viral, but instead it is the emotions that are attached to the content. Emotion is carried, amplified, and harnessed to connect communities or publics, and every tweet 'accrues a tiny affective nugget' ${ }^{123}$ that helps to make legal meaning visible and contestable. Chapter 6 highlights and showcases such affective interactions within the hashtags and comments of the case studies. It does so by describing emotional responses to terror attacks and highlighting connections between these emotions and the legitimacy of law. The chapter further demonstrates that emotional articulations of fear, vulnerability, empathy, and hope in these case studies inscribe individuals and communities into the story itself, thereby petitioning other users towards a sense of communal understanding of legality. It is argued that this cumulative impact of facilitating a shared legal consciousness through which a collective narrative is formed, contributes to the validation and contagion of emotion, which,

122 Richard Sherwin, 'Picturing Justice: Images of Law and Lawyers in the Visual Media' (1996) 30 University of San Francisco Law Review 891.

123 Jodi Dean, Blog Theory: Feedback and Capture in the Circuits of Drive (Polity Press 2010) 95. 
in turn, braids together affect, judgment, and identity to fuel a hashtag jurisprudence.

The combined work of the previous chapters provides an account of hashtag jurisprudence evident in the discourses of terror on social media; a jurisprudence that facilitates judgment, critique and expectation surrounding legality. Bringing the book to its conclusion, the final chapter elucidates the latent potential of hashtag jurisprudence. As such, the chapter concentrates on the threads of narrative subscription that powerfully weave together the fabric of legality within a hashtag jurisprudence: narrative, emotion, and culture. Law's legitimacy depends on trust and faith among individuals. As a complex site of encounter between contemporary culture and law, social media provides access to informally constituted legal practices and ideas, and these ideas and perceptions are fundamental to an effectively functioning society. With each preceding chapter, an account is constructed of the complex and chaotic processes of sense-making and meaning attribution in the aftermath of terrorism. In approaching social media comments as constitutive of ideas about legality, this chapter draws connections between law's legitimacy, institutional trust, and communal expectations of law. It demonstrates that within the contemporary context of terrorism it is possible to generate new knowledge about how law can be challenged by the impact of public emotional responses, and why this is apposite given that we live in an increasingly networked world, where social media platforms amplify and intensify evaluation, interpretation, and critique. As described in Chapter 3 , empirical research into social media from a cultural legal studies perspective is at best nascent, and this chapter offers a new scholarly perspective on the patterns of behaviours that collectively configure law as legitimate or otherwise, and of how such an engagement can be evaluated. 